\title{
Inhibition of IgE and lgE/anti-lgE mediated responses in mast cells by Omalizumab
}

\author{
M Kulka*, A Catalli \\ From Canadian Society of Allergy and Clinical Immunology Annual Scientific Meeting 2009 \\ Halifax, Canada. 22-25 October 2009
}

\section{Background}

IgE binding via the high affinity FceRI receptor modulates FceRI expression and cytokine production in mast cells. Antigen crosslinking of bound IgE further activates mast cells, inducing degranulation and inflammatory mediator release. Omalizumab (Xolair; Genentech Inc) is a recombinant human monoclonal anti-IgE antibody that prevents IgE binding to FceRI.

\section{Objective}

We investigated the effects of omalizumab on IgEmediated responses in human mast cells.

\section{Methods}

LAD2 and CD $34^{+}$-derived human mast cell degranulation was determined by measuring the release of the granular enzyme, $\beta$-hexosaminidase. Toll-like receptor (TLR) expression was measured by quantitative (qPCR) and western blot analysis. IgE binding and FceRI expression was determined by flow cytometry.

\section{Results}

Omalizumab $(10 \mathrm{ug} / \mathrm{mL})$ inhibited IgE binding to LAD2 cells by $78 \%(\mathrm{P}=0.007)$ compared to untreated control. Omalizumab $(10 \mathrm{ug} / \mathrm{mL})$ further blocked IgE-dependent upregulation of FceRI expression by $90 \%(\mathrm{P}=0.03)$. In addition, omalizumab removed FceRI-bound IgE in a time-dependent manner; an effect that was detected as early as $24 \mathrm{hrs}(57 \%$ removal; $\mathrm{P}<0.001)$ after addition of omalizumab resulting in a concomitant decrease in IgEdependent FceRI expression (30\%; $\mathrm{P}<0.001)$. Omalizumab attenuated degranulation induced by anti-IgE crosslinking of bound IgE in a dose dependent manner, with $66 \%$ inhibition $(\mathrm{P}<0.0001)$ at $25 \mathrm{ug} / \mathrm{ml}$. Furthermore, $100 \mathrm{ug} / \mathrm{ml}$ omaluzimab prevented cysteinyl leukotriene

\footnotetext{
* Correspondence: marianna.kulka@nrc-cnrc.gc.ca

National Research Council- INH, Charlottetown, PE, Canada
}

production and FceRI-dependent modulation of TLR expression.

\section{Conclusions}

Omalizumab inhibits IgE and IgE/anti-IgE dependent degranulation and receptor expression by human mast cells. Furthermore, omalizumab is able to remove prebound IgE from sensitized mast cells thereby reducing their response to FceRI-dependent signals. This data suggests that omalizumab is an effective inhibitor of both sensitized and unsensitized human mast cells.

\section{Acknowledgements}

Funded by a collaborative research grant from Genentech, Inc.

Published: 12 May 2010

doi:10.1186/1710-1492-6-S1-P13

Cite this article as: Kulka and Catalli: Inhibition of IgE and IgE/anti-lgE mediated responses in mast cells by Omalizumab. Allergy, Asthma \& Clinical Immunology 2010 6(Suppl 1):P13.
Submit your next manuscript to BioMed Central and take full advantage of:

- Convenient online submission

- Thorough peer review

- No space constraints or color figure charges

- Immediate publication on acceptance

- Inclusion in PubMed, CAS, Scopus and Google Scholar

- Research which is freely available for redistribution

Submit your manuscript at www.biomedcentral.com/submit

\section{() Biomed Central}

